\title{
Efektivitas Kombinasi Senam Hamil dan Konsumsi Sayuran Berdaun Hijau Terhadap Kadar Hemoglobin Ibu Hamil
}

\author{
Ida Farida Handayani ${ }^{1 *}$, Ugi Sugiarsih ${ }^{2}$ \\ 1, 2) Program Studi Kebidanan Karawang, Politeknik Kesehatan Kemenkes Bandung \\ *Corresponding author: ida.ifhe@gmail.com
}

\begin{abstract}
Background: pregnant women with anemia are a global problem because it affects some pregnant women in the world. It is estimated that $41.8 \%$ of pregnant women in the world experience anemia and most of them are due to iron deficiency. Non-pharmacological methods are important related to the consumption of appropriate nutritional intake when pregnant so that iron needs are met, in order to increase the number of red blood cells and form fetal and placental red blood cells, including by consuming green leafy vegetables and doing pregnancy exercise. Purpose: this study aims to determine the effectiveness of a combination of pregnancy exercise and consumption of green leafy vegetables on hemoglobin levels of pregnant women in Karawang Regency in 2019. Methods: this type of research is quasi-experimental, with the pretest-posttest control group design. The population in this study were 59 pregnant women, consisting of 1 treatment group and 1 control group. Results: most of the respondents were not at risk, namely 39 people (67.2\%), 34 people with low education (58.6\%) and 40 people in the second trimester of pregnancy (69\%), it was found that there was a difference in increasing levels. hemoglobin as much as $0.5 \mathrm{gr} / \mathrm{dl}$. Conclusion: there is an effect of a combination of pregnancy exercise and consumption of green leafy vegetables on the hemoglobin level of pregnant women $(p$ value $=0.00)$.
\end{abstract}

Keywords: Hemoglobin Levels, Green Leafy Vegetables, Pregnancy Exercise

\begin{abstract}
ABSTRAK
Latar belakang: wanita hamil dengan anemia merupakan sebuah masalah global karena berdampak pada sebagian wanita hamil di dunia. Sebagian besar ibu hamil di dunia mengalami anemia diperkirakan sebesar $41,8 \%$, dan penyebabnya adalah kekurangan zat besi. Cara non farmakologis yaitu penting terkait konsumsi asupan gizi yang sesuai ketika hamil sehingga kebutuhan zat besi terpenuhi, dalam rangka meningkatkan jumlah sel darah merah dan membentuk sel darah merah janin dan plasenta, yaitu diantaranya dengan mengkonsumsi sayuran berdaun hijau serta melakukan senam hamil. Tujuan: penelitian ini bertujuan untuk mengetahui efektivitas kombinasi senam hamil dan konsumsi sayuran berdaun hijau terhadap kadar hemoglobin ibu hamil di Kabupaten Karawang tahun 2019. Metode: jenis penelitian quasi-experiment dengan desain Pretest-Posttest control Group. Populasi dalam penelitian ini yaitu ibu hamil sebanyak 59 responden, terdiri dari 1 kelompok perlakuan dan 1 kelompok kontrol. Hasil: sebagian besar responden adalah berusia tidak berisiko yaitu sebanyak 39 orang $(67,2 \%)$, berpendidikan rendah sebanyak 34 orang $(58,6 \%)$ dan usia kehamilan trimester II sebanyak 40 orang $(69 \%)$, ditemukan ada ada perbedaan peningkatan kadar hemoglobin
\end{abstract}


sebanyak 0,5 gr/dl. Kesimpulan: ada pengaruh kombinasi senam hamil dan konsumsi sayuran berdaun hijau dengan kadar hemoglobin ibu hamil ( $p$ value $=0,00)$.

Kata kunci: Kadar Hemoglobin, Sayuran Berdaun Hijau, Senam Hamil

\section{PENDAHULUAN}

Wanita hamil di dunia mempunyai masalah global yaitu anemia. Sebesar $41,8 \%$ ibu hamil di dunia mengalami anemia dan sebagian besar dikarenakan kekurangan zat besi, dengan kadar Hb kurang dari $11 \mathrm{mg} / \mathrm{L}$. Kebutuhan zat besi pada pada masa kehamilan yaitu sebesar 1,190 mg. Target pemberian Fe pada ibu hamil tahun 2014 sebesar 95\%, namun cakupan yang didapatkan baru menunjukkan 32,5\%. Laporan Riskesdas 2012 menunjukkan prevalensi anemia pada Wanita Usia Subur (WUS) usia> 15 tahun sebesar 22,7\%, sedangkan pada ibu hamil sebesar $37,1 \%$ $(1,2)$.

Penyebab anemia pada ibu hamil adalah defisiensi zat besi, asam folat dan kelainan darah. Anemia pada ibu hamil mempunyai dampak yang serius pada saat kehamilan, persalinan maupun masa nifas. Dampaknya yaitu gangguan pertumbuhan pada sel tubuh maupun sel otak, mengakibatkan kurangnya oksigen yang ditransfer ke sel tubuh maupun ke otak. Kontribusi anemia dalam kehamilan sebanyak $23 \%$ menjadi penyebab tidak langsung pada kematian ibu di negara berkembang $(2,3)$.

Hemoglobin di bawah $11 \mathrm{gr} / \mathrm{dl}$ meningkatkan risiko kelahiran prematur, berat lahir rendah, dan usia kehamilan kecil pada trimester pertama dan risiko berat lahir rendah pada trimester ketiga (3).

Upaya untuk menurunkan angka anemia pada ibu hamil ada dua cara yaitu secara farmakologis dan non farmakologis. Cara farmakologis yaitu dengan mengkonsumsi suplemen zat besi sebanyak 90 tablet sampai kehamilan trimester III dengan dosis $60 \mathrm{mg}$ tablet $\mathrm{Fe}$ dan 50 nanogram asam folat. Adapun cara non farmakologis yaitu terpenuhinya asupan nutrisi yang sesuai ketika hamil sebagai upaya meningkatkan jumlah sel darah merah serta membentuk sel darah merah janin dan plasenta, diantaranya yaitu dengan mengkonsumsi sayuran berdaun hijau, serta melakukan gerakan senam hamil $(4,5)$.

Senam hamil merupakan terapi latihan gerak guna mempersiapkan ibu hamil, secara fisik maupun mental untuk menghadapi persalinan. Gerakan senam hamil menyebabkan peredaran darah dalam tubuh meningkat dan oksigen yang diangkut ke otot-otot serta jaringan dalam tubuh bertambah banyak. Selain itu senam hamil juga dapat meningkatkan tekanan darah, menyebabkan perubahan tekanan osmotik intramuskular sehingga mendorong air dari kompartemen vaskuler ke ruang interstitial, yang mengakibatkan volume plasma turun dan secara otomatis akan menaikkan kadar hemoglobin $(\mathrm{Hb})$ (6).

Hasil penelitian Wahyuni, 2016 memperlihatkan bahwa ada perbedaan kadar $\mathrm{Hb}$ sebelum dan setelah melakukan senam hamil. Rata-rata kadar $\mathrm{Hb}$ sebelum senam hamil adalah 10,988 meningkat menjadi 12,175 setelah senam (7). Mardianti tahun 2017 dalam penelitiannya menemukan terdapat perbedaan antara kadar hemoglobin ibu sebelum dan setelah senam hamil $(p=0,00)$, senam hamil 
berpengaruh sebesar $5,4 \%$ terhadap peningkatan kadar hemoglobin ibu hamil (8). Renda tahun 2017 dalam penelitiannya juga menunjukkan ada peningkatan ratarata kadar $\mathrm{Hb}$ pada ibu hamil yang melakukan senam hamil sebesar 0,300 dan ada perbedaan bermakna kadar $\mathrm{Hb}$ antara ibu yang melakukan dan tidak melakukan senam hamil (9).

Penelitian Losu dalam Rimawati tentang sayuran berdaun hijau diantaranya pernah ditemukan ada pengaruh konsumsi sayur tinutuan (yang didalamnya berisi kangkung, bayam, jagung, beras) terhadap kadar hemoglobin ibu hamil (10), dalam penelitian lain Rohmatika menemukan ada perbedaan rata-rata $\mathrm{Hb}$ sebesar 0,54 dan ada pengaruh terhadap kadar $\mathrm{Hb}$ pada ibu hamil yang mengkonsumsi ekstrak bayam hijau. Hasil penelitian lain juga menemukan ada pengaruh pemberian jus bayam hijau terhadap kadar hb ibu hamil (11).

\section{METODE}

Penelitian ini menggunakan desain QuasiExperiment dengan rancangan PretestPosttest control Group. Peneliti pengelompokkan anggota kelompok perlakuan dan kontrol berdasarkan acak (random). Setelah itu dilakukan pretest (01) pada kedua kelompok, dan diikuti perlakuan (X) pada kelompok perlakuan (senam hamil dan konsumsi sayuran berdaun hijau) dan kontrol (edukasi tentang nutrisi penting untuk mencegah anemia). Setelah beberapa waktu (4 minggu/1 bulan) dilakukan posttest (02) pada kedua kelompok tersebut. Adapun langkah kegiatannya yaitu: 1) Melakukan pemeriksaan kadar HB pada ibu hamil pada kelompok perlakuan dan kontrol, 2) Pada kelompok perlakuan ibu hamil melakukan senam hamil (dilakukan sebanyak 1x/minggu selama 4 minggu dan mengkonsumsi sayuran berdaun hijau (bayam, kangkung, daun singkong) yang dikukus sebanyak $60 \mathrm{mg} / 1$ cangkir dengan frekuensi $3 x /$ seminggu dalam waktu 4 minggu. Peneliti mengadakan pertemuan dengan responden 1 kali dalam seminggu, selama 4 minggu berturut-turut, dimana pertemuan tersebut diisi dengan kegiatan senam hamil dan konsumsi sayuran hijau bersama-sama, selanjutnya untuk sisa dua kali konsumsi sayuran, peneliti menggunakan lembar monitoring untuk mengontrol konsumsi sayuran hijau yang dilakukan oleh responden di rumah masingmasing. peneliti mengadakan pertemuan 1 kali dalam seminggu selama 4 minggu berturut-turut pada kelompok kontrol dilakukan edukasi tentang nutrisi untuk mencegah anemia dalam kehamilan sebanyak 1 kali. 3) Kelompok perlakuan dan kelompok kontrol dilakukan pengukuran kadar HB setelah dilakukan intervensi (dengan jarak 4 minggu/28 hari dari pemeriksaan pertama). Sampel penelitian adalah ibu hamil dengan usia kehamilan > 22 minggu. Penelitian dilakukan di wilayah kerja Puskesmas Tanjung Pura, Karawang, tahun 2019.

Analisa data menggunakan teknik analisis statistik parametrik, menggunakan uji T-test berpasangan untuk perbedaan pretest dan posttest kadar haemoglobin, dan Uji T-test independen digunakan untuk mengetahui perbedaan pengaruh senam hamil dan konsumsi sayuran hijau terhadap kadar Haemoglobin dengan taraf kesalahan $5 \%$.

Penelitian ini sudah mendapat surat persetujuan kaji etik dari Poltekkes Kemenkes Bandung dengan nomor 73/KEPK/PE/VIII/2019. 
HASIL

Hasil penelitian dapat di lihat pada tabel di bawah ini:

Tabel 1. Distribusi usia, pendidikan, usia kehamilan responden di Kabupaten Karawang Tahun 2019

\begin{tabular}{lcc}
\hline \multicolumn{1}{c}{ Faktor } & F & $\mathbf{( \% )}$ \\
\hline Usia & & \\
Tidak berisiko & 39 & 67,2 \\
Berisiko & 19 & 32,8 \\
Total & $\mathbf{5 8}$ & $\mathbf{1 0 0}$ \\
Pendidikan & & \\
Tinggi & 24 & 41,4 \\
Rendah & 34 & 58,6 \\
Total & $\mathbf{5 8}$ & $\mathbf{1 0 0}$ \\
Usia Kehamilan & & \\
Trimester II & 40 & 69 \\
Trimester III & 18 & 31 \\
Total & $\mathbf{5 8}$ & $\mathbf{1 0 0}$ \\
\hline
\end{tabular}

Berdasarkan tabel 1 didapatkan sebagian besar responden adalah berusia tidak berisiko yaitu sebanyak 39 orang $(67,2 \%)$, berpendidikan rendah sebanyak 34 orang $(58,6 \%)$ dan usia kehamilan trimester II sebanyak 40 orang (69\%).

Tabel 2. Distribusi Rata-rata Kadar Hemoglobin Responden Pada kelompok Intervensi Menurut Pengukuran Pertama dan Kedua di Kabupaten Karawang Tahun 2019

\begin{tabular}{cccccc}
\hline Variabel & Mean & SD & SE & $\begin{array}{c}P \\
\text { value }\end{array}$ & $N$ \\
\hline
\end{tabular}

\begin{tabular}{cccccc}
\hline Kadar Hb & & & & & \\
Pengukuran I & 10,576 & 0,97 & 0,18 & 0,00 & 29 \\
Pengukuran II & 11,069 & 0,86 & 0,16 & & 29 \\
\hline
\end{tabular}

Berdasarkan tabel 2 diatas,

ditemukan nilai rata-rata $\mathrm{Hb}$ kelompok intervensi pada pengukuran pertama yaitu 10,58 dengan standar deviasi 0,97 dan ratarata $\mathrm{Hb}$ pada pengukuran kedua meningkat menjadi 11,07 dengan standar deviasi 0,16. Terlihat perbedaan nilai mean antara pengukuran pre dan post adalah 0,5. Hasil uji didapatkan nilai 0,00 maka dapat disimpulkan ada perbedaan yang bermakna antara kadar $\mathrm{Hb}$ pengukuran pre dan post, dengan kata lain ada pengaruh senam hamil dan konsumsi sayuran berdaun hijau dengan kadar hemoglobin ibu hamil.

Tabel 3. Distribusi Rata-rata Kadar Hemoglobin Responden Pada kelompok Kontrol Menurut Pengukuran Pertama dan Kedua di Kabupaten Karawang Tahun 2019

\begin{tabular}{cccccc}
\hline Variabel & Mean & SD & SE & $\begin{array}{c}P \\
\text { Value }\end{array}$ & N \\
\hline Kadar Hb & & & & & \\
Pengukuran I & 10,531 & 1,40 & 0,26 & 0,01 & 29 \\
Pengukuran II & 10,100 & 1,16 & 0,21 & & 29 \\
\hline
\end{tabular}

Berdasarkan tabel 3 diatas, ditemukan nilai rata-rata $\mathrm{Hb}$ kelompok kontrol pada pengukuran pertama yaitu 10,531 dengan standar deviasi 1,40 dan rata-rata $\mathrm{Hb}$ pada pengukuran kedua yaitu 10,100 dengan standar deviasi 1,16. Hasil uji statistik didapatkan nilai 0,01 maka dapat disimpulkan ada perbedaan yang signifikan antara kadar $\mathrm{Hb}$ pengukuran pertama dan kedua.

Tabel 4. Perbandingan Kadar $\mathrm{Hb}$ pada Kelompok Intervensi dan Kelompok Kontrol pada Pemeriksaan Awal pada Ibu Hamil di Kabupaten Karawang Tahun 2019

\begin{tabular}{cccc}
\hline Kelompok & Rata-rata & SD & $\begin{array}{c}\text { Un-paired } \\
\text { “t”Value }\end{array}$ \\
\hline Intervensi & 10,58 & 0,966 & $\mathrm{~T}=0,142$ \\
Kontrol & 10,53 & 1,401 & $P=0,88$ \\
\hline
\end{tabular}

Berdasarkan tabel 4 perbedaan rata rata kadar pemeriksaan awal $\mathrm{Hb}$ pada kelompok intervensi dan kelompok kontrol adalah 0,05. Hasil uji statistik menemukan nilai $p=0,88$ maka dapat disimpulkan tidak ada hubungan yang bermakna antara hasil pemeriksaan $\mathrm{Hb}$ awal pada kelompok intervensi dan kelompok kontrol. 
Tabel 5. Perbandingan Kadar $\mathrm{Hb}$ pada Kelompok Intervensi dan Kelompok Kontrol pada Pemeriksaan Akhir pada Ibu Hamil di Kabupaten Karawang Tahun 2019

\begin{tabular}{cccc}
\hline Kelompok & $\begin{array}{c}\text { Rata- } \\
\text { rata }\end{array}$ & SD & $\begin{array}{c}\text { Un-paired } \\
\text { "t } \boldsymbol{t} \text { Value }\end{array}$ \\
\hline Intervensi & 11,06 & 0,86 & $\mathrm{~T}=3,609$ \\
Kontrol & 10,10 & 1,155 & $P=0,01$ \\
\hline
\end{tabular}

Pada tabel 5 terlihat perbedaan rata rata pemeriksaan akhir $\mathrm{Hb}$ pada kelompok intervensi dan kelompok kontrol adalah 0,96 . Hasil uji statistik menemukan nilai $p=0,01$ maka dapat disimpulkan ada perbedaan yang bermakna antara hasil pemeriksaan $\mathrm{Hb}$ akhir pada kelompok intervensi dengan kelompok kontrol.

\section{PEMBAHASAN}

Berdasarkan tabel 2 diatas, ditemukan nilai rata-rata $\mathrm{Hb}$ kelompok intervensi pada pengukuran pre yaitu 10,58 dengan SD 0,97 dan rata-rata $\mathrm{Hb}$ pada pengukuran post yaitu 11,07 dengan SD 0,16. Terlihat rata rata perbedaan antara pengukuran pre dan post atau peningkatan rata-rata $\mathrm{Hb}$ adalah $0,5 \mathrm{gr} / \mathrm{dl}$. Hasil uji didapatkan nilai P 0,00 maka dapat disimpulkan ada perbedaan yang bermakna antara kadar $\mathrm{Hb}$ pengukuran pre dan post. Sehingga dapat dikatakan ada pengaruh antara kombinasi senam hamil dan konsumsi sayuran berdaun hijau dengan kadar hemoglobin ibu hamil.

Peningkatan kadar hemoglobin pada penelitian ini yaitu $0,5 \mathrm{gr} / \mathrm{dl}$, hal ini berbeda dengan hasil penelitian Kundaryanti Rini, 2018 di Jakarta Selatan, yang menemukan peningkatan rata-rata kadar hemoglobinnya sebesar 1,23 gr/dl dengan mengkonsumsi sebanyak $500 \mathrm{ml}$ jus bayam selama 7 hari (12). Hasil penelitian ini sama dengan penelitian yang dilakukan oleh Rohmatika (2016) di Surakarta yang menemukan rata- rata peningkatan kadar $\mathrm{Hb}$ setelah intervensi (pemberian ekstrak bayam hijau selama 7 hari) sebesar 0,54 gr/dl (11), hasil penelitian ini lebih tinggi dibandingkan penelitian Mardianti 2018, yang menemukan peningkatan kadar $\mathrm{Hb}$ setelah senam hamil sebanyak 0,38 gr/dl (8).

Kadar Hemoglobin rata-rata responden sebelum perlakuan yaitu 10,58 gr\% setelah intervensi yaitu 11,07 gr\%. Hasil penelitian Wahyuni, 2016 melaporkan bahwa terdapat peningkatan kadar hemoglobin sebelum dan setelah melakukan senam hamil dengan rata-rata kadar $\mathrm{Hb}$ sebelum senam hamil adalah 10,988 mengalami peningkatan menjadi 12,175 setelah senam (7), sedangkan penelitian Kundaryanti menemukan nilai rata-rata kadar hemoglobin sebelum perlakuan yaitu 9,03 gr/dl dan setelah perlakuan 10,26 gr/dl (12).

Hasil penelitian ini sama dengan yang dilaporkan Kundaryanti (2018) dan Adhawiah bahwa ada hubungan antara konsumsi sayuran berdaun hijau (jus dan ekstrak bayam) dengan kadar hemoglobin ibu hamil. Hasil penelitian ini juga sama dengan hasil penelitian Mardianti 2018 yang menemukan ada hubungan antara senam hamil dengan kadar hemoglobin ibu hamil $(8,12)$.

Mardianti dalam penelitiannya menemukan ada perbedaan rata-rata kadar Hemoglobin pada responden yang melakukan senam hamil dengan peningkatan sebesar 0,38. Hal ini lebih kecil dibandingkan perbedaan $\mathrm{Hb}$ pada penelitian ini $(0,5)$. Sehingga kombinasi senam hamil dengan konsumsi sayuran berdaun hijau cukup efektif untuk meningkatkan kadar $\mathrm{Hb}$ ibu hamil. Namun demikian, hasil penelitian ini masih rendah bila dibandingkan hasil penelitian 
Kundaryanti, yang menemukan perbedaan kadar Hb sebanyak 1, 23 gr/dl (8).

Wahyuni, 2016 melaporkan bahwa ada peningkatan kadar $\mathrm{Hb}$ pre dan post dengan rata-rata kadar $\mathrm{Hb}$ pre adalah 10,988 meningkat menjadi 12,175 (7). Mardianti tahun 2017 dalam penelitiannya menemukan perbedaan antara kadar hemoglobin ibu sebelum dan setelah senam hamil $(\mathrm{p}=0,00)$, senam hamil dapat berpengaruh sebesar 5,4 \% terhadap peningkatan kadar $\mathrm{Hb}$ pada ibu hamil (8). Renda tahun 2017 dalam penelitiannya juga menunjukkan ada peningkatan rata-rata kadar $\mathrm{Hb}$ pada kelompok perlakuan sebesar 0,300 dan ada perbedaan bermakna kadar $\mathrm{Hb}$ antara ibu yang melakukan dan tidak melakukan senam hamil (13).

Kadar hemoglobin pada wanita hamil lebih rendah dibanding dengan wanita yang tidak hamil. Hal ini disebabkan pada wanita yang sedang hamil terjadi perubahan konsentrasi pada volume darahnya. Peningkatan konsentrasi volume darah pada wanita hamil mempengaruhi penurunan kadar $\mathrm{Hb}$. dan peningkatan volume eritrosit. Peningkatan tersebut lebih banyak ditambahkan pada plasma ke dalam sirkulasi ibu, akibatnya kadar hematokrit dan hemoglobin mengalami menurun (5).

Selama masa kehamilan ibu dianjurkan untuk mengkonsumsi tablet $\mathrm{Fe}$ yang mengandung $60 \mathrm{mg}$ zat besi setiap harinya, di samping itu sayuran berdaun hijau, diantaranya bayam hijau juga mengandung zat besi sebesar 3,9 mg/100 gr bayam (12).

Senam hamil merupakan latihan yang dilakukan dalam rangka yang mempersiapkan ibu hamil secara fisik dan mental dalam menghadapi persalinan. Gerakan gerakan pada senam hamil dapat menyebabkan darah dalam tubuh ibu hamil meningkat dan oksigen yang diangkut ke otot-otot dan jaringan tubuh semakin bertambah banyak. Gerakan pada senam hamil dapat meningkatkan tekanan darah dan menyebabkan perubahan pada tekanan osmotik dan intramuskular sehingga dapat mendorong air dari kompartemen vaskuler ke dalam ruang interstitial, sehingga volume plasma turun dan secara otomatis dapat meningkatkan kadar $\mathrm{Hb}$ (6).

Latihan berupa senam hamil yang dilakukan oleh ibu hamil dapat menurunkan volume plasma, total protein dan konsentrasi albumin (protein utama yang terdapat dalam darah yang diproduksi oleh hati) secara bermakna. Kegiatan senam hamil dapat mempengaruhi penurunan volume plasma, akhirnya konsentrasi $\mathrm{Hb}$, hematokrit dan jumlah sel darah merah akan meningkat dan mencapai titik keseimbangan.

Mardianti dalam penelitiannya menemukan ada perbedaan rata-rata kadar Hemoglobin pada ibu hamil setelah melakukan senam hamil, dengan peningkatan sebesar 0,38. Hal ini lebih kecil dibandingkan perbedaan $\mathrm{Hb}$ pada penelitian ini $(0,5)$. Sehingga kombinasi senam hamil dengan konsumsi sayuran berdaun hijau cukup efektif untuk meningkatkan kadar $\mathrm{Hb}$ ibu hamil, dibandingkan hanya dengan senam hamil saja. Namun demikian, peningkatan kadar hemoglobin dalam penelitian ini masih rendah bila dibandingkan hasil penelitian Kundaryanti, yang menemukan perbedaan kadar $\mathrm{Hb}$ sebanyak 1,23 gr/dl.

Berdasarkan tabel 5 perbedaan ratarata kadar pemeriksaan akhir $\mathrm{Hb}$ pada kelompok perlakuan dan kelompok kontrol adalah 0,96. Hasil uji ditemukan nilai $p=0,01$ maka peneliti menyimpulkan ada perbedaan yang bermakna antara hasil pemeriksaan $\mathrm{Hb}$ akhir pada kelompok intervensi dan kelompok kontrol. Sehingga 
dapat dikatakan ada perbedaan peningkatan kadar hemoglobin pada kelompok yang melakukan senam hamil dan konsumsi sayuran berdaun hijau dibandingkan dengan kelompok kontrol.

Hasil penelitian ini juga sama dengan hasil penelitian tentang sayuran berdaun hijau diantaranya pernah ditemukan ada pengaruh konsumsi sayur tinutuan (yang di dalamnya berisi kangkung, bayam, jagung, beras) terhadap kadar hemoglobin ibu hamil, dalam penelitian lain Rohmatika menemukan terdapat perbedaan rata-rata kadar $\mathrm{Hb}$ sebesar 0,54 dan ada pengaruh terhadap kadar $\mathrm{Hb}$ pada ibu hamil yang mengkonsumsi ekstrak bayam hijau. Hasil penelitian lain juga menemukan ada pengaruh pemberian jus bayam hijau terhadap kadar $\mathrm{Hb}$ Ibu hamil (14).

Jenis sayuran berwarna hijau tua seperti: daun katuk. bayam, kangkung, daun singkong, daun pepaya, daun kacang panjang, sawi, banyak mengandung asam folat, vitamin A, vitamin B, vitamin C, dan. Selain itu, sayuran berdaun hijau tua juga banyak mengandung unsur mineral seperti magnesium, fosfor zat besi dan zat kapur.

Sayuran berdaun hijau tua, mengandung serat yang tinggi, magnesium, kalium, kalsium dan zat besi. Selain itu sayuran hijau tua juga mengandung sedikit karbohidrat, sodium, kolesterol, dan karotenoid. Karotenoid merupakan antioksidan yang akan melindungi sel-sel tubuh yang penting untuk menghambat tahap perkembangan awal sel kanker. Satu cangkir bayam yang dimasak mengandung lebih dari $6 \mathrm{mg}$ zat besi, vitamin A, vitamin E protein, serat, dan kalsium.(4).

Konsumsi makanan yang tepat oleh ibu hamil sangat penting untuk memenuhi kebutuhan gizi selama masa kehamilan. Salah satu kebutuhan nutrisi penting ibu selama masa kehamilan yang harus terpenuhi adalah zat besi. Zat besi banyak terdapat pada sayuran yang berwarna hijau gelap/tua, seperti daun katuk, kangkung, bayam, daun kacang panjang dan lain-lain. Makanan yang banyak mengandung zat besi (Fe) bisa membantu meningkatkan produksi hemoglobin dalam darah.

Zat Besi dari makanan diserap ke usus halus, semakin ke distal absorpsinya semakin berkurang. Zat ini lebih mudah diserap dalam bentuk ferro melalui pengangkutan ion ferro yang sudah diabsorpsi diubah menjadi ion ferri dalam mukosa usus. Ion ferri akan masuk ke dalam plasma dengan perantara transferin yang diubah menjadi feritrin yang di simpan di dalam sel mukosa. Apabila simpanan zat besi total tinggi dan kebutuhan besi tubuh rendah, maka zat besi yang baru di absorpsi langsung diangkut dari sel-sel mukosa ke sumsum tulang untuk produksi $\mathrm{Hb}$.

Senam hamil terdiri dari beberapa gerakan. Gerakan pada senam hamil tersebut dapat meningkatkan tekanan darah dan menyebabkan penurunan tekanan osmotik intramuskular kemudian mendorong air dari kompartemen vaskuler ke ruang interstisial sehingga jumlah volume plasma turun dan secara otomatis dapat meningkatkan kadar $\mathrm{Hb}$.

Walaupun hasil dari penelitian ini bermakna, dimana secara statistik ditemukan hubungan antara kadar hemoglobin sebelum dan setelah dilakukan intervensi, serta ada perbedaan peningkatan kadar hemoglobin pada pemeriksaan akhir dalam kedua kelompok. Peningkatan kadar hemoglobin pada penelitian ini rata-rata lebih rendah dibandingkan hasil penelitian lain, hal ini kemungkinan dikarenakan responden hanya mengkonsumsi sayuran berdaun hijau sebanyak $3 \mathrm{kali} / \mathrm{minggu}$ sebanyak $60 \mathrm{mg} /$ hari. Peneliti berasumsi 
jika ibu hamil melakukan senam hamil di kombinasikan dengan mengkonsumsi sayuran berdaun hijau setiap hari sebanyak 100 gr/hari, maka akan lebih efektif untuk meningkatkan kadar hemoglobin ibu hamil, dengan perbedaan peningkatan kadar $\mathrm{Hb}$ yang lebih besar dibandingkan dengan penelitian ini dan penelitian-penelitian sebelumnya.

Penelitian ini bersifat untuk menginisiasi dan merupakan sebuah gerakan kecil yang sederhana, dimana berupaya mendorong ibu hamil untuk mengkonsumsi sayuran berdaun hijau secara teratur, dan memasukan jenis sayuran ini dalam daftar menu sehari-hari mereka, selain jenis makanan lain yang banyak mengandung zat besi, seperti daging-dagingan, buah-buahan serta sayuran berwarna lainnya untuk mencegah anemia, dengan cara meningkatkan kadar hemoglobin.

Selain itu ibu hamil juga didorong untuk rutin melakukan senam hamil secara teratur yang dimulai sejak usia kehamilan 22 minggu (tanpa penyulit) dan tentunya sudah berkonsultasi terlebih dahulu dengan bidan setempat. Senam hamil bisa ibu hamil lakukan baik secara mandiri maupun secara berkelompok pada saat kunjungan ke kelas ibu hamil. Senam hamil tersebut selain bermanfaat selama kehamilan, juga merupakan salah satu persiapan ibu menjelang persalinan.

Mengkonsumsi tablet $\mathrm{Fe}$ selama kehamilan merupakan sebuah upaya besar dan penting bagi ibu hamil untuk meningkatkan kadar hemoglobin ibu sehingga dapat mencegah kejadian anemia selama kehamilan. Ibu hamil disarankan untuk mengkonsumsi tablet Fe selama 90 tablet dengan dosis $60 \mathrm{mg}$ untuk meningkatkan kadar hemoglobin selama hamil.
Jika semua ibu hamil rutin mengkonsumsi tablet $\mathrm{Fe}$, ditambah dengan rutin melakukan senam hamil dan mengkonsumsi sayuran berdaun hijau serta makanan lain yang banyak mengandung zat besi, maka bukan hal yang mustahil semua ibu hamil dapat terbebas dari anemia, sehingga secara tidak langsung dapat berkontribusi dalam menurunkan angka kesakitan dan kematian pada ibu dan bayi yang disebabkan oleh anemia. Selain itu dengan terbebas dari anemia, merupakan gerbang utama dalam mewujudkan generasi emas yang handal dengan terpenuhinya zat gizi yang seimbang bagi tumbuh kembang janin selama kehamilan.

\section{KESIMPULAN}

Berdasarkan hasil penelitian pada 58 responden, maka dapat disimpulkan yaitu nilai rata-rata $\mathrm{Hb}$ kelompok intervensi pada pengukuran pre yaitu 10,58 dengan standar deviasi 0,97 dan rata-rata $\mathrm{Hb}$ pada pengukuran post mengalami peningkatan menjadi 11,07 dengan standar deviasi 0,16. Nilai rata-rata $\mathrm{Hb}$ kelompok kontrol pada pengukuran pre yaitu 10,53 dengan SD 1,40 dan $\mathrm{Hb}$ rata-rata pada pengukuran post yaitu 10,10 dengan SD 1,16. Perbedaan rata-rata kadar hemoglobin sebelum dan setelah intervensi (peningkatan kadar $\mathrm{Hb}$ ) yaitu sebesar 0,5 gr/dl. Ada pengaruh kombinasi senam hamil dan konsumsi sayuran berdaun hijau terhadap kadar $\mathrm{Hb}$ ibu hamil di area Kerja Puskesmas Tanjung Pura Karawang tahun 2019.

\section{UCAPAN TERIMAKASIH}

Ucapan terima kasih penulis sampaikan kepada pihak Direktorat Poltekkes Kemenkes Bandung, khususnya bagian SUPPM dan komite kaji etik, serta kepada pengelola Program Studi Kebidanan Karawang. 


\section{KONFLIK KEPENTINGAN}

Kami sebagai tim peneliti menyatakan bahwa penelitian ini tidak mengandung unsur konflik kepentingan, dan tidak memiliki afiliasi atau koneksi/hubungan atau dengan organisasi apapun..

\section{REFERENSI}

1. Kementerian Kesehatan Republik Indonesia. Situasi Kesehatan Ibu [Internet]. Jakarta; 2014. Available from:

https://pusdatin.kemkes.go.id/resour ces/download/pusdatin/infodatin/inf odarin-ibu.pdf

2. Stephen G, Mgongo M, Hussein Hashim T, Katanga J, StrayPedersen B, Msuya SE. Anaemia in Pregnancy: Prevalence, Risk Factors, and Adverse Perinatal Outcomes in Northern Tanzania. Anemia. 2018;

3. Sukrat B, Wilasrusmee C, Siribumrungwong B, McEvoy $\mathrm{M}$, Okascharoen C, Attia J, et al. Hemoglobin Concentration and Pregnancy Outcomes: A Systematic Review and Meta-Analysis. Biomed Res Int [Internet]. 2013;2013:1-9. Available from: http://www.hindawi.com/journals/b mri/2013/769057/

4. Yanti Aprilia Rina. Anemia dan Vitamin [Internet]. 2017. Available from:

https://docplayer.infi/91095166anemia-dan-vitamin

5. Saifuddin A B. Buku Acuan Nasional Pelayanan Kesehatan maternal dan Neonatal. Jakarta: Yayasan Bina Pustaka Prawirohardjo; 2016.

6. Prasetyo Yudik. Olahraga Bagi Wanita Hamil. In. Available from: http://staffnew.uny.ac.id/upload/132 308484/penelitian/Olahraga_Bagi_ wanita_Hamil.pdf

7. Wahyuni NQ. Pengaruh Senam Hamil Terhadap Perubahan Kadar Hemoglobin (hb) Pada Kehamilan trimester Ketiga. J Kesehat [Internet]. 2010;3. Available from: https://publikasiilmiah.ums.ac.id/bis tream/handle/11617/2902

8. Mardianti. Pengaruh Senam Hamil Terhadap Kadar Hemoglobin pada Ibu Hamil di wilayah Kerja Puskesmas Rengasdengklok Karawang. J Kebidanan Indones [Internet]. 2018;9(1). Available from:

https://jurnal.stikesmus.ac.id/index. php/JKebln/articles

9. Renda Natalina P RA aminah. Perbandingan Senam Hamil dan Edukasi tentang Anemia Terhadap Kadar Hemoglobin $(\mathrm{Hb})$ pada Ibu Hamil. E J Stikes MP. 2017;

10. Rimawati E, Kusumawati E, Gamelia E, Achadi Nugraheni S, Kesehatan F, Dian Nuswantoro U, et al. Intervensi Suplemen Makanan Untuk Meningkatkan Kadar Hemoglobin Pada Ibu Hamil Food Supplement Interventions for Increasing Hemoglobin Level on Pregnant Women. J Ilmu Kesehat Masy. 2018;9(3):161-70.

11. Rohmatika D. Efektivitas Pemberian Ekstrak Bayam terhadap Peningkatan Kadar Hemoglobin pada Ibu Hamil dengan Anemia Ringan. J Kebidanan. 2017;9(2):165-74.

12. Kundaryanti R, M NF, Widowati R. Pengaruh Pemberian Jus Bayam Hijau Terhadap Peningkatan Kadar Hemoglobin pada Ibu Hamil Anemia 
Di Wilayah Kerja Puskesmas Pasar Minggu Jakarta Selatan Tahun 2018. Ilmu Keperawatan dan Kebidanan Nas. 2019;

13. Natalina PR, Aminah MR. Perbandingan Pengaruh Senam Hamil dan Edukasi Tentang Anemia Terhadap Kadar Hemoglobin (HB) Pada Ibu Hamil. J Masker Med. 2017;5(2):472-88.

14. Dheny Rohmatika, Supriyana DR. Perbandingan Pengaruh Pemberian Ekstrak Bayam Hijau Dengan Preparat Fe Terhadap Perubahan Kadar Hemoglobin Ibu Hamil. J Kesmadaska. 2016;7(1):60-8. 